June 25, 1844 .

William Horton Lloyd, Esq., in the Chair.

"Description of some new species of Birds brought by Mr. L. Fraser from Western Africa," by H. E. Strickland, Esq., M.A.

Mr. Fraser has placed in my hands for examination and description a portion of the ornithological collection made by him during the Niger expedition, and I now present the names and characters of the new species. Mr. Fraser's researches in Western Africa have made us acquainted with several new and interesting species of birds, and as he was only able to bring horne very few, and in some cases only one specimen of each species, it would be very desirable that full descriptions, illustrated by figures, of these ornithological rarities should be made public, especially as it may be long before the pesti. lential shores of Western Africa are again explored by naturalists.

\title{
Hirundinide, Cypseitne.
}

Cypselus parvus, Licht., Verz. Doubl. p. 58.

A specimen of this bird was brought by Mr. Fraser from Acra; it is probably the smallest species of the genus, the total length being only 6 inches, wing $4 \frac{3}{4}$ inches, medial rectrices $1 \frac{3}{4}$ inch, external $3 \frac{1}{4}$ inches. Plumage uniform mouse-colour, chin whitish.

Acanthylis bicolor (Gray); Chetura bicolor, Gray, Zool. Misc. p. 7.

A specimen of this elegant little species was obtained in May 1842 at Fernando Po, where it was very common.

\section{Turdide, Malurine.}

Prinia olivacea, Strickl. $P$. suprid viridi-olivacea, remigibus fuscis, olivaceo limbatis, cauda caneatd, rectricibus duobus intermediis fuscis, lateralibus albis, extùs fusco marginatis, extimo toto albo; mento corporeque toto inferno albido, pallidè flavo lavato. Rostrum pedesque fuscescentes.

The aspect of this bird is that of a Phylloscopus, but the beak is longer, more depressed at the base, the culmen carinated, the wings short and rounded, the first quill subspurious, the fourth longest; tail much graduated, rectrices narrow ; tarsi moderately long, acrotarsia scutate, toes slender, the outer longer than the inner. These characters induce me to class the bird provisionally in the genus Prinia.

'Total length $4 \frac{\mathrm{I}}{2}$ inches; beak to gape 6 lines, to front $5 \frac{1}{2}$ lines, breadth 2 lines, height $1 \frac{1}{2}$ line ; wing $1 \frac{3}{4}$ inch; medial rectrices 1 inch 10 lines, external 1 inch 1 line; tarsus $7 \frac{1}{2}$ lines, middle toe $5 \frac{1}{2}$ lines, hind ditto 5 lines.

$H a b$. Fernando Po; June 1842. 
Prinia ICterica, Strickl. P. supri flavo-olivacea, loris, superciliis, genis, margine alarum, tibiis, caudaque tectricibus infernis latè flavis, mento, guld, pectore et abdomine albidis, pallidè isabellino lavatis, hypochondriis favo-olivaceis, rostro nigro, pedibus rubris.

This bird appears to belong to the same group as the last, but the beak is rather more depressed, the tail shorter and less cuneate, and the tarsi rather longer. In all other respects their structures correspond. They both have short rictal bristles and the nostrils are large, oblong, and situated in a large membranous depression of the beak. Possibly they may hereafter form a distinet genus of Malurince, distinguished chiefly by the depressed form of the beak.

Total length $3 \frac{3}{4}$ inches; beak to gape $7 \frac{1}{2}$ lines, to front 6 lines, breadth $2 \frac{1}{4}$ lines, height $1 \frac{1}{2}$ line ; wing 1 inch 11 lines; medial rectrices $1 \frac{1}{4}$ inch, external 1 inch; tarsus $9 \frac{1}{2}$ lines, middle toe $6 \frac{1}{2}$ lines, hind ditto $5 \frac{1}{2}$ lines.

$H a b$. Fernando Po; June.

Mr. Fraser adds : "Irides light hazel ; note tweet, tweet, tweet, hopping about the topmost branches of a small tree like a wren." In a sketch of this bird by Mr. Fraser the tail is erect, as in Troglodytes.

\section{Turding.}

Cossypha poensis, Strickl. C. corpore suprà fuliginoso-fusco,

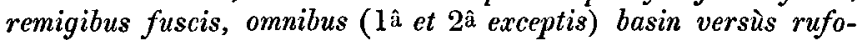
ferrugineis, sed scapis fuscis; rectricibus fuscis, tribus externis utrinque albo terminatis (qui color in rectricis extima pogonio ext erno obliquè versus basin producitur), corpore toto inferno ferrugineo, guld obscuriore. Rostrum atrum, pedes flavescentes.

Seems to be a typical Cossypha, allied to C. reclamator (Vieill.), with which it agrees in all essential characters. The specimen above described is a male, and was procured at Clarence, Fernando Po.

Total length $7 \frac{3}{4}$ inches; beak to gape 10 lines, to front 7 lines, breadth 4 lines, height $2 \frac{1}{2}$ lines; wing 4 inches 2 lines; medial rectrices $3 \frac{1}{2}$ inches, external 3 inches 4 lines; tarsus 1 inch, middle toe and claw 1 inch, hind ditto 8 lines, lateral toes equal.

Mr. Fraser adds that this bird " feeds on the ground; when sitting quiet in a naked bush it is with difficulty to be discovered. Irides hazel."

\section{Pycnonotina.}

Andropanus latikostris, Strickl. A. corpore suprà olivaceo, remigibus fuscis, extùs viridi-olivascente, intìs albido, marginatis, rectricibus fusco-brunneis, olivaceo limbatis; corpore subtùs olivascente, lateribus menti, alce tectricibus infernis, et abdomine medio stramineis, Rostrum corneum, marginibus pallidis, pedes unguesque pallescentes. Rostrum depressum, tomiorum dentibus obiiquis 6 vel 7 utrinque; illis maxilla distinctis, mandibula subobsoletis.

In this species the beak is considerably depressed and formed like that of a Muscicapa; the teeth of the upper mandible are distinct and regular, but disappear about the middle of the beak. The lower 
mandible is also furnished with five or six serrations, but very low and indistinct. The wing is much rounded, the fifth quill being longest and the rest graduated. The colour and texture of plumage are much like that of the East Indian Pycnonotus flavirictus, Strickl. (Ann. Nat. Hist., June 1844.)

Total length $6 \frac{3}{4}$ inches; beak to gape 11 lines, to front 7 lines; breadth 4 lines, height $2 \frac{1}{2}$ lines; wing $3 \frac{1}{4}$ inches; medial rectrices 3 inches; external $2 \frac{3}{4}$ inches; tarsus $\frac{3}{4}$ inch, middle toe and claw 8 lines, hind ditto 6 lines.

The above description is taken from a specimen marked " female." In two other specimens in which the sex is not indicated the dimensions and plumage are the same, but the yellow streak on each side of the chin is wanting, and the lower mandible wants the serrations, and exhibits only a small subterminal notch. 'These are probably younger individuals.

Hab. Fernando Po; June.

Andropadus gracilirostris, Strickl. A. corpore toto suprà olivaceo, remigibus primariis fuscis, extùs olivascente, intùs pallidè ochraceo limbatis, corpore subtùs pallidè olivaceo-cinerascente, mento gulâque albidlis, abdomine medio crissoque pallidè flavescentibus, alarum tectricibus infernis pallidè ochraceis. Rostrum pedesque corneo-fusci; rostrum longiusculum, turdinum, dentibus maxille duobus, mandibula nullis.

This species differs from the former one in several points of structure ; the beak is considerably narrower at the base and more slender, the upper mandible has only two dentations, with a faint trace of a third, and the lower mandible exhibits only a slight subterminal emargination. The wings also differ, being more pointed; the first quill is subspurious, and the second, third and fourth nearly equal, the third longest. These two species, however, agree in the structure of the tail and feet, and in the texture and almost the colour of the plumage, the rump-feathers being dense, long and downy, as in the true Pycnonoti. The specimen before me is a male; it exhibits two or three slender nuchal bristles, like those of Pycnonotus and Criniger, which are not traceable in $A$. latirostris.

Total length 7 inches; beak to gape 10 lines, to front 7 lines, breadth 3 lines, height $2 \frac{1}{2}$ lines; wing $3 \frac{1}{4}$ inches; medial rectrices 3 inches 1 line, external 2 inches 11 lines; tarsus $9 \frac{1}{2}$ lines, middle toe and claw 9 lines, hind ditto 6 lines.

$H a b$. Fernando Po ; June. "Irides white; a pretty songster."

\section{Muscicapide, Muscicapine.}

Muscicapa Fraseri, Strickl. M. capite, dorso alisque fuscis, ferrugineo tinctis, remigibus fuscis, primariis ext ùs basin versus obscurè ferrugineis, omnibus, $1 \hat{a}$ et $2 \hat{a}$ exceptis, pogoniis internis ad basin pallide rufis, uropygio, caude tectricibus, corporeque toto inferno rufo-ferrugineis, gula pallidiore, rectricibus fuscis, 6 intermediis strictissimè, lateralibus largè, rufo terminatis, externo ferè omninò rufo. Rostrum latum, nigrum, pedes pallidè brunnei. 
The rufous colouring of the plumage reminds us of Tchitrea, Less. (Muscipeta, Auct.), but the beak is much shorter and more triangular than in that genus. In its general structure and proportions this bird appears to approach the restricted genus Muscicapa more closely than any other group. The form of the beak is almost exactly that of the Muscicapa latirostris, Sw., of India, and the legs are much shorter than is usual in terrestrial birds. Notwithstanding these characters, Mr. Fraser's notes state that this bird " feeds on the ground; has the motions and plump appearance of a robin." $\mathrm{He}$ adds that the irides are hazel, and that it is a beautiful songster.

The beak is strong, depressed, very broad, the sides straight when viewed from above, and the base furnished with bristles of moderate length. The first quill is subspurious, 1 inch long; the second is half an inch shorter than the third; the fourth is the longest. Tarsi short, acrotarsia and paratarsia entire; outer toe slightly longer than the inner one, its first phalanx attached to the middle toe; claws curved, compressed, sharp; tail rounded. The male and female are alike, except that in the specimen before me of the female the narrow rufous tip of the medial rectrices is wanting, and the dimensions are rather less than in the male.

Total length $7 \frac{1}{4}$ inches; beak to gape 9 lines, to front 6 lines, height $2 \frac{1}{4}$ lines, breadth at gape 6 lines; wing 3 inches 10 lines; medial rectrices $3 \frac{1}{4}$ inches, external 3 inches 1 line; tarsus 10 lines, middle toe and claw 9 lines, hind ditto 7 lines.

Hab. Fernando Po.

I dedicate this species to Mr. Louis Fraser, naturalist to the Niger expedition, who succeeded in bringing home many interesting additions to zoological science, notwithstanding the difficulties and dangers by which he was surrounded.

\section{Lanimde, LaniIne.}

Tephrodornis ocreatus, Strickl. T. capite suprà genisque fuscoatris, dorso toto alisque obscurè fusco-plumbeis, remigibus rectricibusque fusco-atris, extùs plumbeo limbatis, corpore toto inferno albo, gutturis pectorisque plumis cinereo strictè marginatis, alarum tectricibus infernis cinereis albo marginatis. Rostrum pedesque atri, acrotarsiis integris.

This bird approaches sufficiently near to the Indian genus Tephrodornis to be classed with it, the only important structural differences being that the acrotarsia are entire and that the tail is slightly rounded. The beak resembles that of T. Indica (Gray), but is a trifle shorter; the nostrils are concealed by incumbent bristly feathers; the fourth, fifth and sixth quills are nearly equal, the first three graduated, and the outer toe longer than the inner.

Total length $6 \frac{3}{4}$ inches; beak to gape 11 lines, to front 7 lines, breadth 3 lines, height $2 \frac{1}{2}$ lines; wing 3 inches 7 lines; medial rectrices 3 inches, external 2 inches 8 lines; tarsus 10 lines, middle toe 9 lines, hind ditto 7 lines.

Hub. Fernando Po; June. "Irides hazel, legs blue." 
Mr. Gould laid upon the table a number of Skins of Animals and Birds, being part of a large collection which Mr. Gilbert had lately forwarded to him from Australia. Mr. Gould characterized the following species :-

\section{MAMMALIA.}

Macropus Gracilis. M. infrà incanescens et saturatè fuscus; colli lateribus rufescenti-fusco lavatis; genis, mento et guld fulvescente-albis, vellere molli, ad basin cinereo, exinde fusco, dein albo, apice nigro; pilis longis nigris crebrè interspersis.

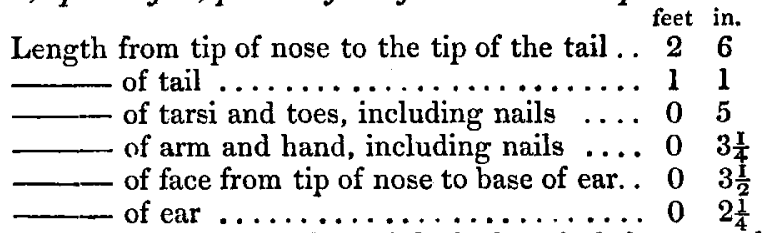

Face and all the upper surface of the body grizzled grey and dark brown, the grizzled appearance produced by each hair being greyish white near its tip; sides of the neck and the outer side of the limbs washed with reddish brown; margin of the anterior edge and the base of the posterior edge of the ear buffy white; line from the angle of the mouth dark brown; line along the side of the face, chin and throat buffy white; under surface buffy grey; tail clothed with short grizzled hairs, similar to the upper surface of the body, and with a line of black on the upper side at the apex for about one-third of its length; the fur, which is somewhat soft to the touch, is grey at the base, then brown, to which succeeds white, the points of the hairs being black; there are also numerous long black hairs dispersed over the surface of the body ; feet grizzled grey and rufous.

This is a very elegantly formed little animal, and is intermediate in size between Macropus lunatus and Macropus franatus.

Hy PSIPRymNus platyops. H. facie magnopere latd; hac, corporisque lateribus, fuscescente-cinereis ; dorso rufescenti-fusco; facie, partibusque superioribus pilis longis, et favido-albis inter vellus crebrè adspersis; corpore inferiore fulvescente-cinereo.

Length from tip of the nose to the extremity of the tail .. 17

$\longrightarrow$ of tail .................... 7

— of tarsi and toes, including nails $\ldots \ldots \ldots \ldots 0028$

—

— of face from tip of nose to base of ear . . . . . 0

Face extremely broad, and, with the sides of the body, brownish grey; back reddish brown; the whole of the face and upper surface beset with numerous long yellowish white hairs, offering a strong contrast to the darker colouring of the fur; all the under surface and limbs buffy grey; tail brown above, paler beneath.

'Mor-da,' aborigines of Western Australia.

'The above is the description of a female received from Swan River. 
Perameles arenaria. $P$. vellere rigido et cinerascente-fusco, pilis longis nigris intermixto, his fasciam lateralem vix distinctam, notamque instar ephippii ad dorsum medium efficientibus; auribus ferrugineis ad basin, in medio saturatè fuscis, ad apicem cinerascente-fuscis; corpore inferiore fulvescente-albo.

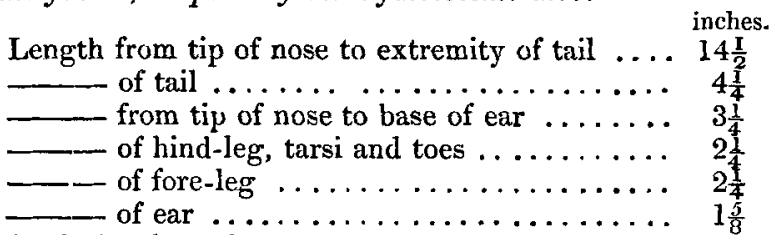

The fur is harsh to the touch and of a greyish brown hue, interspersed with numerous long black hairs, which form a broad indistinct band down the flanks, immediately before the hind-legs, and a kind of saddle-like mark on the centre of the back ; ears rather lengthened and of three colours-rusty red near the base, then dark brown, and the apex of a light greyish brown; sides of the muzzle and all the under surface buffy white; line along the upper surface of the tail dark brown, the remainder buffy white; outside of the fore-legs dark brownish grey; feet and claws buffy white.

Hapalotis longicaudata. H. supernè pallidè arenaced, pilis longis, nigris, ad caput et dorsum cum vellere intermixtis; rostri lateribus, et abdomine albis; cauda pilis brevibus nigris ad basin indutd, upicem versùs nigris et elongatis; apice extremo albo vellere molli, adpresso et juxta cutem plumbeo.

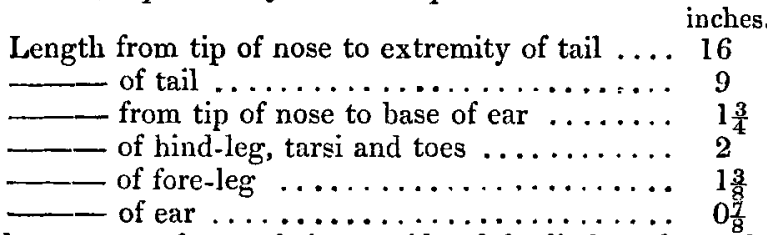

All the upper surface and the outside of the limbs pale sandy, interspersed on the head and over the back with numerous fine black hairs, which, becoming longer on the lower part of the back and ruinp, give that part a dark or brown hue; ears naked and of a dark brown; sides of the muzzle, all the under surface and the inner surface of the limbs white; tail clothed with short dark brown hairs at the base, with lengthened black hairs tipped with white on the apical half of its length, the extreme tip being white; tarsi white; whiskers very long, fine, and black; the fur is close, very soft, and of a dark slaty grey at the base, both on the upper and under surface.

This species is considerably smaller than Hapalotis albipes, but has a much longer tail and longer hind-legs in proportion to the size of the body.

'Kor-tung' and ' Goota-was,' aborigines of Moore's River, Western Australia.

Phascogale calunue. Phasc. cinerea; subtùs pedibusque albis, 
indistinctissimè flavo-tinctis; caudd corpore longiore, dimidio basali pilis brevibus, rufis, apicali pilis longis nigris obsila; auribus magnis ad basin pilis flavescentibus obsitis.

Length from tip of nose to extremity of tail

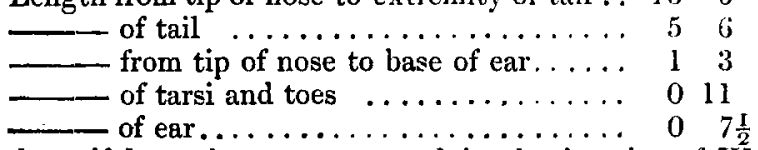

This beautiful species was procured in the interior of Westem Australia.

It is nearly allied to $P$. penicillata, but is of smaller size and has the tail less bushy; the portion covered with short hair is extended from the base nearly to the middle of the tail, and is remarkable for its brilliant rusty-red colour; on the apical half of the tail the hairs are long, being on an average about half an inch in length; all the under side is black, very nearly to the root. The fur is soft and moderately long, and its general colour is ashy grey externally, but grey next the skin; the under parts of the body are white, tinted with cream-colour, and this last-mentioned tint is very distinct on the sides of the body; the eye is encircled by a narrow black line, and there is a blackish patch in front of the eye. The ears are large and very sparingly clothed for the most part with very minute dusky hairs, but at the base, both externally and internally, are some longish yellow hairs.

Phascogale crassicaudata. Phasc. supri cinerea flavo-tincta; corpore subtis, pedibusque albis ; auribus mediocris, externè maculd nigra ornatis; caudd brevi crassâ.

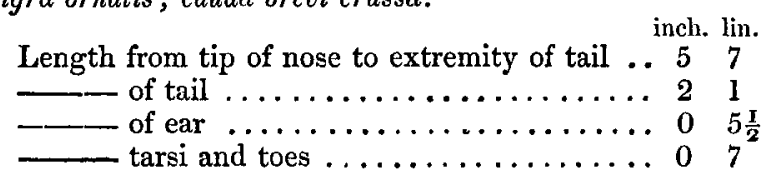

$H a b$. Western Australia.

This species is about the size of the common mouse, and is not unlike the Mus sylvaticus in its colouring; above grey with a wash of yellow, and on the sides of the body distinctly tinted with yellow; under parts and feet pure white; tail much swollen, especially in the middle, and clothed throughout with very minute pale hairs; ears clothed with pale hairs, but with a largish black spot externally; eyes encircled with black hairs; fur moderately long and soft.

\section{AVES.}

IERACIDEA OCCIDENTAIIS. Ier, vertice et corpore superiore ferrugineo-fuscis; singulis plumis strigd centrali nigrd angustè notatis ; cauda fusco multi-fasciatâ; corpore subtùs albo plumis líneâ fuscâ angustd notatis.

Crown of the head, back and scapularies rusty brown, with a narrow stripe of black down the centre; rump deep rusty brown, crossed 
by broad bands of dark brown, the tip of each feather buffy white; wings very dark brown; the inner webs of the primaries with a series of large spots, assuming the form of bars, of a deep rusty brown near the shaft and fading into buffy white on the margin; wing-coverts tipped with rusty red; spurious wing with a row of rusty red spots on either side of the shaft; tail dark brown, crossed by numerous broad irregular bars of rusty red, and tipped with pale buff; earcoverts and a stripe running down from the angle of the lower mandible dark brown; chin, all the under surface, and a broad band which nearly encircles the neck, white, with a fine line of dark brown down the centre; thighs deep rust-red, each feather with a line of black down the centre and tipped with buffy white; cere very light greenish flesh-colour; irides wood-brown; sjace round the eye pale yellow, becoming brighter near the eye; base of the upper mandible, the under mandible and gape, very light horn.colour; tip of the upper mandible black.

'Total length, 16 inches ; bill, $1 \frac{1}{4}$; wing, $12 \frac{1}{2}$; tail, $7 \frac{3}{4}$; tarsi, $2 \frac{1}{2}$.

$H a b$. Western Australia.

Agotheles leucogaster. AE. quoad colorem AE. Nov. Hollandiae consimilis, at grandior, rostro longiore, et abdomine albo.

Head black ; crown, lunar-shaped mark at the back of the head, and a collar surrounding the neck, black, freckled with grey in the centre of each feather; back freckled black and white; wings brown, crossed by numerous bands of lighter brown, freckled with dark brown; primaries margined externally with buff, interrupted with blotchings of flark brown; tail dark brown, crossed by numerous broad irregular bands of reddish buff, freckled with dark brown; ear-coverts strawwhite; chin, abdomen and under tail-coverts white; breast, sides of the neck, and a narrow collar surrounding the back of the neck, white, crossed by numerous narrow freckled bars of black; irides dark brown; upper mandible dark olive-brown, lower white, with a black tip; legs pale yellow, claws black.

Total length, $9 \frac{1}{2}$ inches; bill, 1 ; wing, $5 \frac{3}{4}$; tail, 5 ; tarsi, 1 .

$H a b$. Port Essington.

Malurus pulcherrimus. Mal. Mas: vertice, et fascia dorsali splendidè violaceo-caruleis; orbitis et plumis auricularibus ex arugine caruleis; gulâ indico-caruled, nigro subtùs indistinctè marginatd; plumis scapularibus castaneis; loris, nuchd, et dorso imo holoserico-nigris. Fœm. : fusca, subtìs pallidior, orbitis rubidè fuscis.

Crown of the head and a broad band across the centre of the back rich glossy violet-blue; space surrounding the eye and the ear-coverts verditer-blue; throat intense indigo-blue, bounded below by an indistinct band of black; lores, collar surrounding the back of the neck, and the lower part of the back, deep velvety black; scapularies chestnut; wings brown; tail dull greenish blue, indistinctly barred with a darker tint and slightly tipped with white; abdomen and under tailcoverts white; bill and feet black; irides dark brown. 
Female dull brown, paler beneath; tail-feathers like those of the male, but less bright; bill and space round the eye reddish brown.

Remarks.-Very similar in its markings and general contour to M. Lamberti; it may however be always distinguished from that species by its larger size and by the deep indigo-blue colour of the throat and chest, which parts are black in $M$. Lamberti.

Total length, $5 \frac{1}{4}$ inches; bill, $\frac{9}{16}$; wing, 2 ; tail, $3 \frac{1}{4}$; tarsi, $\frac{15}{1 \frac{5}{5}}$.

$H a b$. Western Australia.

Pachycephala Gidentir. Pach. Mas : colore saturatè olivaccofusco; capite plumbeo; loris nigris; gulá ferruginea; humeris subtùs, abdomine medio, crissoque arenaceis. Fœm. differt, loris non nigris, neque guld ferrugined.

The plumage dark greyish olive-brown; the head dark slate-grey, and the breast of a lighter grey ; the lores black ; throat rust-red; under surface of the shoulder, centre of the abdomen and under tailcoverts sandy buff; irides light brown; bill and feet black. The female is similar in colour, but is destitute of the black on the lores and the red on the throat.

Total length, $6 \frac{3}{4}$ inches; bill, $\frac{1}{1} \frac{1}{6}$; wing, $3 \frac{7}{8}$; tail, $3 \frac{3}{8} ;$ tarsi, 1.

$H a b$. Western Australia. 